Etnográfica

Revista do Centro em Rede de Investigação em

Antropologia

vol. 13 (2) | 2009

Vol. $13(2)$

\title{
Scaling cigars in the Cuban tourism economy
}

Configurar a escala dos charutos na economia do turismo em Cuba

\section{Valerio Simoni}

\section{(2) OpenEdition \\ Journals}

\section{Electronic version}

URL: https://journals.openedition.org/etnografica/1331

DOI: 10.4000/etnografica.1331

ISSN: 2182-2891

\section{Publisher}

Centro em Rede de Investigação em Antropologia

\section{Printed version}

Date of publication: 1 November 2009

Number of pages: 417-438

ISSN: 0873-6561

\section{Electronic reference}

Valerio Simoni, "Scaling cigars in the Cuban tourism economy", Etnográfica [Online], vol. 13 (2) | 2009,

Online since 26 January 2012, connection on 11 February 2022. URL: http://journals.openedition.org/ etnografica/1331; DOI: https://doi.org/10.4000/etnografica.1331

\section{(c) (i) (9)}

Etnográfica is licensed under a Creative Commons Attribution-NonCommercial 4.0 International License. 


\title{
Scaling cigars in the Cuban tourism economy ${ }^{1}$
}

\section{Valerio Simoni}

\begin{abstract}
Taking scale as an object of analysis (Tsing 2000), this article examines how competing scale-making projects emerge in different layers of the Cuban tourism economy. I consider how tourists and Cubans interact along contested chains of production and distribution of cigars, and therefore become entangled in bundles of ideas, discourses, practices and materialities. These constitute different scaling propositions on which tourists and Cubans converge or diverge, and which inform the success of encounters within the tourism economy. Highlighted is the importance of understanding how scaling propositions are enacted and negotiated within tourism. I conclude that the realm of tourism is a particularly fruitful platform to investigate how competing scale-making projects and notions of scale are played out in the contemporary world.
\end{abstract}

KEYWORDS: cigars, Cuba, economy, scale, tobacco, tourism.

\section{INTRODUCTION}

The success story and world mystique of the Havana cigar started five centuries ago (Stubbs 2004: 135). Since then, Cuban cigars have stimulated people's imagination. As the island was further integrated into the global economy cigars became ever more a part of a wide range of narratives concerning Cuba and its relations with the world. Their long history is grounded in their uniqueness as exceptional artefacts and objects of particularly high quality. Thus, it is

I This article builds on a paper given at the conference "Things that Move: The Material Worlds of Tourism and Travel", Leeds, 19-23 July 2007 (Simoni 2007). I would like to thank the editors of this dossier, Patrick Neveling and Carsten Wergin, for their constant encouragement, support, and helpful comments on this paper. My gratitude also goes to the anonymous reviewers of the article for their stimulating and thought-provoking remarks and recommendations. Finally, this paper would not have been possible without the collaboration of the several tourists and Cubans I encountered during my seven months of fieldwork between 2005 and 2007. Nevertheless, all mistakes and shortcomings are on my behalf, of course. 
of no surprise that they have found a prominent place in the island's tourism development.

Tourists travelling to Cuba may view the country as the last communist bastion resisting the global victory of capitalism and the constant pressures of its mighty neighbour, the US. Thus, Cuba has become a sort of living laboratory where tourists can make up their mind about how well "this system" works in respect to "theirs". The chain of production and distribution of cigars is one of the particular testing grounds for such assessments. State authorities promote visits to sites where cigars are produced and encourage their purchase. The same officials also highlight the "success story" of Cuban cigars as an example for the smooth and coherent functioning of Cuban economy and society. However, this positive evaluation of the "Cuban way" is not the only reality that emerges. The aim of this article is to show how tourists' diverse encounters with the worlds of cigars in Cuba are best understood by examining them as competing processes of scale-making (see also Neveling and Wergin 2009 , this volume).

My approach to the issue of scale and processes of scale-making is to shift from analytical attempts to establish scales a priori - be it "global", "transnational", "local", etc. - to a consideration of actors" own situated processes of scaling and notions of scale. In recent decades, scales as processes and social constructions have received increased attention in human geography (see in particular the works of Smith 1993; Marston 2000; Brenner 2001; Swyngedouw 2004). These seminal works have analysed scales as hierarchically ordered arenas of struggle. While acknowledging the relevance of this corpus of research, this article moves a step further and adopts a more open-ended approach to scale, using detailed ethnography to highlight not only simultaneous and competing processes of scale-making, but also how different notions of scale (cf. Moore 2008) were enacted in the Cuban tourism economy. Once scaling is not considered as something to be settled by the analyst but rather as an object of analysis, close attention can be paid to the processes through which actors bring about certain scales and elaborate on scale.

The scaling of Cuba as a unique, unified, and coherent entity is conveyed and materialised by the deployments of cigars in the official tourism realm. Besides the scale-making project enacted by the Cuban tourism industry, I consider other projects central to informal street-deals, for example, which albeit relationally informed by the former - disrupt the reality of an all-encompassing and smoothly functioning "communist economic system". This draws attention to a range of controversies and struggles which have issues of scale at their core, and whose results can have profound and dramatic implications for the livelihood of the Cuban people at stake. Thus, once we delve deeper into a variety of cigar deployments in the realm of tourism, other "projects of scale-making" emerge as "attention to these processes provides an alternative 
to the conflation of varied scale-making claims, projects, and agents" (Tsing 2000: 347).

The following sections examine tourists' encounters with the worlds of cigars in official factory tours in Havana, in the course of informal deals in the streets of the capital, and finally encounters with tobacco farmers in the valley of Viñales. The cases presented will show how the boundaries between these different encounters and the respective scale-making projects - far from always being clear-cut and stable - are contested and renegotiated. In the conclusion, I elaborate on what can be learned from this journey along controversial chain(s) of production and distribution of cigars, and how this helps to better understand issues of scale in tourism.

TOBACCO FACTORIES, CIGAR SHOPS, AND THE SCALING OF "COMMUNIST COMMODITIES"

Cigar factory tours are among the highlights recommended for all tourist visits to Havana. On these tours, official guides explain the production of cigars while visitors follow the different operations that lead to the confection of cigars. During my visits, guides highlighted the subdivision of different manufacturing tasks from the selection of leaves to the meticulous application of labels and their packaging into boxes. On such tours, cigars were presented as entangled within a web of specialized operations and rigorous controls based on the collaborative effort of skilled workers. In the main factory room, where (secretly) assorted leaves were rolled into cigars, the visitors' attention was drawn to a stage facing the workers. Whereas in other factories this would be the place where the supervisors sit, in this case, twice a day professional readers entertain workers with news and novels. ${ }^{2}$ Tourists were presented with an image of educated citizens making up a workforce in tune with the Cuban government's policy ever since the Revolution of 1959. To further promote the idea of a nonalienating form of labour guides emphasised that workers had the right to consume a certain amount of cigars. But in relation to the factory's total output few cigars were consumed by the workers who had produced them. Instead, the final stages of each tour illustrated processes of disentanglement and "marketization" (Callon 1998) that turned cigars into stabilized and standardized commodities. These explanations culminated in the application of labels to cigars and cigar boxes. Indeed, following the visit to the main manufacturing room, tourists were guided through the checks that guaranteed that cigars conformed

2 See the article by the Cuban journalist García Galló (2005 [1961]) for a historic perspective on this practice praising its contribution to the formation of Cuba's national character. For a perspective on surveillance in factories and strategies of de-alienation in capitalist production regimes, see Neveling (2006). 
to the required standards. Next came the areas where cigars were carefully ordered into boxes and finally labelled as particular brands. Guarantee seals, labels, brands and logos were thus portrayed as crucial elements through which cigars could be recognised and authenticated. In the factory shop, tourists were then invited to use their freshly acquired knowledge, choose the brands they wanted to buy and relate the qualities of different products to their budgets. In line with Busch, I understand these processes of standardisation as part of a "moral economy" of the market according to which, "grades and standards are ways of [...] defining what [in this case cigars, V.S.] is good and what is bad, of disciplining those people and things that do not conform to the accepted definition of good and bad" (2000: 274). ${ }^{3}$ In conformity with this moral economy of the market, tourists buying cigars in state-owned shops were given receipts and guarantees that entitled them to export these "communist commodities".

In order to understand why and how these tours helped the scale-making project of the Cuban state work, it is necessary to explain the notion of "marketization" in more detail. Processes of "extrication" of cigars from the manufacturer as well as their subsequent framing as commodities are fruitfully illuminated through the analytical notions of entanglement/disentanglement (Thomas 1991; Callon 1998). Indeed, this marketization of Cuban cigars - as many other such processes of alienating objects in order to become commodities - "implies investments and precise actions to cut certain ties and internalize others" (Callon 1998: 19). Projects of scale-making rely on processes of entanglement and disentanglement like the ones at work in Havana factories because these contribute to frame, define, and qualify what pertains to the scales that the wider projects aim to achieve. The most obvious and easy to follow example for such a project is the reification of Cuban cigars' unique qualities as signified by labels and other embodiments of their reputation and history. The public display of the secret assortment of leaves as their central ingredient is another such staged reality and matches Marston's (2000) considerations on scale as a framing process. Reviewing social constructionist approaches to scale, Marston establishes a process very similar to the staged confection of cigars on these tours, where scale first was "a way of framing conceptions of reality" (Delaney and Leitner 1997, quoted in Marston 2000: 221 ) and secondly, where "the outcomes of these framings [...] are tangible and have material consequence" (Marston 2000: 221$).{ }^{4}$ Combining and going

3 However, in line with Neveling's and Wergin's considerations on the potential flexibility of moralities (2009, this issue), the following sections show that the moralities brought about in cigar factories were not the only ones at stake in Cuba's tourism economy. Indeed, other projects of scale-making, which relied on other standards and regimes of value, contributed to evoke other moral orders.

4 In a later section of this paper I will address the third of these analytical qualities, namely that "the framings of scale [...] are often contradictory and contested and are not necessarily enduring" (Marston 2000: 221). The pertinence of all these three points will reappear throughout this article. 
beyond the otherwise unconnected considerations of Marston and Callon I therefore argue that further insights can be gained by viewing framings simultaneously as results of scales (cf. Marston 2000) and as producers of scales through processes of entanglement/disentanglement (cf. Callon 1998). Instead of giving a priori precedence to one perspective over the other, a combination of the two highlights how scaling and framing can bring about each other in a reciprocal way. In the case of Havana's factory tours, once we follow processes of entanglement/disentanglement, we understand how the framing at stake progressively extricates cigars from the work of those who have manufactured them. Disentangled via this extrication, cigars can then be sold to tourists in the factory shop as commodities. Thus, cigars have been pushed onto a demarcated stage reserved for commodities circulating within the tourism economy (Slater 2002: 242). ${ }^{5}$

Most tourists considered that authentic Cuban cigars - faithful to their brands and reputations - could be best accessed in these shops where the various brands were displayed in showcases with labels and prices, and where information could be obtained from officially appointed sellers in an air-conditioned and carefully illuminated atmosphere, resembling museum displays (Figure 1). It was here that those who wanted to be sure of quality and receive long-term commitments and guarantees came to do their purchases. The notion of a morally "good" market transaction was enhanced by the carefully regulated environment of the shop, the sellers' behaviour, the cash registers, exact prices, boxes, labels and the like. The sale of some of the most celebrated and expensive cigar brands like

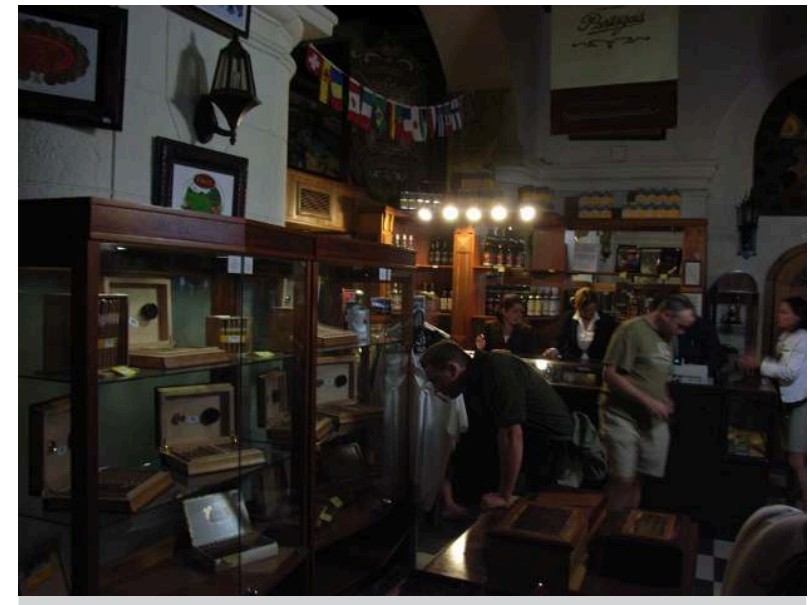

Figure 1 - Inside a cigar shop, Partagas Factory, Havana. (Photo by Simoni, 2006)

5 This is where my ethnographic material can be useful to clarify the difference between notions of entanglement/disentanglement and Polanyi's notion of embedding and disembedding. Whereas in his concept "society appears as a container or framework that assigns a particular location to the economic, and is therefore capable of separating out culture and economy" to disentangle objects is, like it happens in Cuban cigar factories, grounded in a different process. "It is frankly dialectical, and this dialectic is played out, with only temporary stabilization, without cease. [...] Disentanglement, therefore, $[\ldots]$ does not signify the disembedding of the economy in the sense of a separation of economy from culture; it is rather a reframing of culturally meaningful items" (Slater 2002: 242). 
Cohiba, Montecristo (respectively Fidel's and Che Guevara's favourites) and Romeo y Julieta was thus based on a dialectically-framed relation involving the professionalism and seriousness of a well-performing state (represented by the shops' personnel and set-up) and the disciplined and morally acting tourist.

The deployments of tobacco and cigars in factories and shops brought about the ideal of a communist Cuba which functioned smoothly and was able to produce world-class commodities. This process was portrayed as a totality with skilful farmers providing top-quality leaves, educated manufacturers processing them and efficient and competent sellers distributing the final product: the Cuban cigar as a "communist commodity", a unique piece of manufacture, "100\% Cuban", able not only to integrate and compete with the rest of the world, but the best among all cigars. Embodying the "proper commodity chain of cigars", all the processes leading to this achievement were portrayed to the tourists as taking place under the savvy supervision of the Cuban authorities who provided the necessary infrastructure.

Just around the corner of the factories, however, this ideal picture of cigars as the result of a joint Cuban effort in a smoothly functioning, stately-run process was disrupted by informal cigar deals regularly offered to tourists. These deals constituted another important layer of the island's tourism economy and provided economic resources to many of its inhabitants. They were part of a realm of activities which is often referred to in Cuba as jineterismo (literally horseback riding) - a term which evokes notions of hustling tourists and prostitution (Palmié 2004), and which accounts for a variety of intersections between tourism and the informal economy (cf. Cabezas 2004; Kummels 2005; Simoni 2008a, 2008b, 2008c). After our short tour through the staterun cigar factory and shop, I now consider these street-deals and the ways in which they entangled cigars to other scales and notions of scales.

\section{STREET-DEALS IN HAVANA: RE-SCALING COMMODITY EXCHANGE}

Walking the streets of Old Havana, tourists were regularly proposed streetdeals. The objects of these deals, cigars that had been diverted from the "proper", state-supervised commodity chain, were advertised as bargains. ${ }^{6}$ The environments in which these offers were made often indicated their shadowy and informal character: street corners or entrances to private houses allowed for secrecy of transactions. At the same time, the frequency of such offers intensified in the proximities of cigar factories and shops. As

6 These cigars had either been smuggled out of factories or confectioned in alternative locations. Diverting cigars or (as shown later) labels, guarantee seals and receipts from official channels required the complicity of state employees and most probably factory workers. However, data on such illegal processes were hard to corroborate also because several contradictory stories circulated among my informants. 
the following section shows, proximity to state-run factories and shops in many cases should prove to be an authorisation for these informal deals. Particularly male employees of factories and shops, notably door keepers, were involved in this trade.

With a cautious tone in their voice, dealers made reference to famous brands like Cohiba and Montecristo and to prices in factories. These precautions outline the crucial tensions traversing all street-deals: they were of potentially high risk to the dealers as sales outside official channels could lead to legal sanctions, i.e. fines and arrests, and the sale of good products at supposedly "fair prices" involved a high degree of persuasion and trust on both sides. A common element was the emphasis on the good value of the products introduced by comparison to prices in official shops. A box of Cohiba or Montecristo was offered at prices ranging from 30 to 100 CUC (pesos convertibles) ${ }^{7}$ instead of 180 to 300 (sometimes up to 500) CUC that had to be paid - as dealers would underline - "for the same product" in the "tiendas del Estado", the shops controlled by the state. Because the difference in prices was substantial, street-deals especially appealed to those tourists travelling with a limited budget. If one could not afford to spend the equivalent of 200-500 Us dollars on a box of cigars sold in official shops, these bargain prices were tempting. Dealers tried to capitalise on exactly these feelings when they asked tourists "not to trust" the state shops because products there were overpriced and supposed to cheat tourists. Even more so, dealers qualified their prices as based on the "real", "objective" value of cigars. While there was no need to explain that a profit for the dealer was included it was obvious to most tourists that this profit was provided for by the primacy of pesos convertibles in the Cuban economy (see note 7). This profit of a few "precious" CUC could suffice to a dealer to qualify a transaction as a "good deal".

One particular project of scale-making targeted the state-run shops. Tourists and dealers shared a widespread narrative that portrayed the Cuban government as abusing its monopole over the economy in order to squeeze as much money as possible out of tourism. This intersection of discourses promoted complicity between Cubans and tourists and informal transactions could be

7 US dollars had been circulating legally from 1993 until 2004 in Cuba. From then on, the dollar was banned by the government and pesos convertibles (CUC, already available on the island since 1991) were declared as mediating currency. The official exchange rate of convertibles was I to I with US dollars but, during my fieldwork, any official exchange of dollars in Cuba was charged a 10\% commission. Most Cubans received their salaries in moneda nacional (MN, "national currency", also called pesos cubanos). But many essential consumer goods were only available - formally at least - in "tiendas de recaudación de divisas" (stores for the recollection of foreign currency) that accepted only convertibles. Between 2005 and 2007, one convertible was worth approximately 25 pesos cubanos. Given this state of affairs, one can easily imagine that the convertibles tourists possessed were coveted by Cubans trying to get hold of this currency as part of their day-to-day lucha (struggle) to get by. A realm of this lucha was tourism. Tourism-oriented activities like the sale of cigars on the street were often labelled as jineterismo (see above). 
portrayed as a way for both sides "not to get cheated by the state". As I argue, these transactions embodied the ideal of a free-market exchange between equal individuals who engaged in the liberal adjustment of exchange values and prices free of the discriminating surcharges stemming from the privileged economic position of tourists. Thus, at least on the discourse level, a "liberal commodity exchange" replaced the "communist commodity exchange" and together with it the vision of a smoothly functioning Cuban economy and society under the benevolent supervision of the state as exhibited on the factory tours.

But in order to complete street-deals successfully, the complicity between self-interested individuals willing to maximize profits without much consideration for the wider societal scale of the nation needed to be grounded in more than just a narrative. The following section concerns the ways in which cigars sold on Havana's streets were entangled in scale-making projects of two kinds: the already indicated disentanglement of cigars from the state project of scaling them as "communist commodities" and an inverted movement of (playfully) (re-)entangling commodities in these informal deals with the state policy of labelling, branding and standardisation.

Besides emphasising how fair the prices of their offers were in comparison to what the state-run shops asked for a box of cigars, dealers mobilised several other moral frames to counter those of the state. These are to be understood as opposed to the "market standardisation processes" highlighted earlier, in line with Busch's considerations (2000). Instead, dealers evoked morals like "family budgets" or "labour solidarity". One street vendor argued that he offered cigars at "family prices" while standing next to the entrance of a Havana cigar factory. Others offered cigars at "workers" prices", thereby creating a direct link of producers to their products, portrayed as stripped from "price-inflating" bureaucratic detours in official distribution channels. Often, an alternative version of "communist commodity exchange" was brought forward when dealers interpreted communist class ideas to their own advantage. One man framed this straightforwardly when he argued that he offered "socialist prices", referring to a socialist exchange without hierarchies and thus including Cubans and tourists alike. All these discourses created a disjuncture with the world of state supervision and distribution. Whether a "liberal" exchange model was enacted, or the ideal of a more immediate and encompassing form of socialism, the state was cast as a disentangled, separate, and potentially manipulative entity. A scale of more immediate and "horizontal" economic relationships emerged that could only become true when the state was bypassed.

But in the course of many street-deals, the moralities attached to market standardisation and formalisation resurfaced at a later stage. They were co-opted back to shed good light on these informal transactions. Although 
frequently highlighting fair prices, dealers tried to re-connect and re-entangle their free-floating cigars with the world of factories, state-supervised production, and official branding in order to disentangle them from the realm of illegality and brand forgery. To achieve this, it was necessary to re-introduce the Cuban state as an authority in the field of cigar production as soon as a tourist's attention was secured. Dealers argued that their cigars came straight from the factory because they themselves or some of their close friends or kin worked there and were therefore experts/professionals in the field. Further associations with legally sanctioned sales were aimed at, when propositions were made just outside factories and official shops. Those working as door keepers of shops profited from uniforms and official badges that gave them a privileged position. Their attire and fittings regularly caught the attention of tourists entering and leaving the shops and gave them authority when they suggested a better deal. Others, lingering around a factory reassuringly displayed a badge identifying them as factory workers to tourists. Addressing tourists before they entered the shop or the factory, these dealers suggested to first have a look inside, check out prices, and then come back to buy at a better price. "Want to see or want to buy?", a man asked me and my company as we were filming outside a factory. According to him, the factory shop was the place to "see" because an idea of the official prices would allow tourists to appreciate his prices even more. There was also a second rationale to his remarks, as he would not loose time explaining the range of different cigars to tourists in order to initiate a high-risk and legally-sanctioned activity with no guarantee that a deal would be accomplished in the end. If the shop was the place to see, the man outside the factory said that purchases were best made on the "market of the factory workers", where official bills as well as everything else necessary to get the cigars through customs at departure would be provided for.

The issue of compliance with customs requirements was central to the later stages of many informal deals. Sometimes, fake receipts were given to tourists and often logos and other legal inscriptions had been carefully applied to cigar boxes sold in street-deals. The purpose was to enable tourists to bring the cigars out of the country without problems. These "officialisations" were explicitly negotiated because holographic stamps or bills added to the price of a box. Thus, a parallel version of the entanglements and scale-making processes taking place in state-run shops existed with the same devices (logos, bills, etc.) as in legalised market exchanges manipulated to (re)enact the very same regulations. This "informal" standardisation deconstructed - in complicity of dealers and tourists - the official scaling projects set up to indicate "proper" cigar distribution. This enactment was one constitutive relationship creating and subsuming the difference between formal and informal layers in the Cuban tourism economy. While the state sought to carve out differences by labelling, 
branding, and employing other regulatory devices, the co-optation of the same devices in informal economic activities subsumed this very process. ${ }^{8}$

Despite efforts to "formalise" exchanges, many tourists remained sceptical and considered street-deals risky and illegal rather than trusted in the staged version of official sanction. This was so because informal deals lacked the material elements attributed by the state to official purchases, particularly air conditioned rooms, shop counters, museum-like displays of cigar boxes, cash registers, etc. These were inalienable devices indicating strict quality controls and market standardisation at the heart of the government's scale-making project. The presence or absence of the same devices also shaped the forms of transaction both in formal and in informal exchanges. In state-run shops transactions hardly required further proof of the commodity's conformity to standards whereas in street-deals, tourists' uncertainty about the cigars' quality and authenticity predominated.

To strengthen the image of high-quality, real "branded" cigars on sale, dealers tried to channel attention to the internal features of cigars. Their underpinning rationale was the following: even tourists who were suspicious of the nature of the deal could be convinced that the only thing that mattered was the quality and the price of the cigars themselves. This meant that dealers would draw attention to colour, texture, internal composition, smell, flexibility, and finally the taste and burning qualities of a cigar in order to prove its excellence. In really tough cases dealers even proposed to open a cigar and to jointly examine its interiors in a kind of autopsy as the ultimate proof of authenticity. ${ }^{9}$ As a last resort, tourists were encouraged to smoke a cigar, to taste its quality and to judge additional indicators such as the way the cigar burnt, the colour of the ashes and their consistence.

Unlike the process of relating cigars to factories or the status of the seller, the restriction of the focus to their own qualities was supposed to "cut networks" (Strathern 1996) and narrow the frame of elements relevant to potential buyers. Dealers thus tried to increase control over the authentication process by making certain indicators pertinent and then proving them immediately to

8 Swyngedouw (2004) highlights a distinction between scales of regulation and governance on the one hand, and networked scales of economic activities on the other. While this conception of scalar configurations as either regulatory orders or networks may fruitfully illuminate the case considered here, such clear cut distinction appears less pertinent when considering other examples discussed in this article. To avoid any risk of reification and grant more subtlety to the analytical insights, I suggest considering such divides, and the tensions they generate, only once they emerge in a given context, rather than erect them as analytical starting points.

9 Stories about the circulation of "fake Cuban cigars" and about the possibility of being cheated date back at least to the $17^{\text {th }}$ century. In a text published in Edinburgh in 1614, Dr. William Barclay warned of the deceptive appearance cigars could be given by their external coats to cover tobacco of an inferior quality. Barclay thus came to the conclusion that the best tobacco was the one sold in leaves, and not rolled (Ortiz 2005 [1940]: 104-108). 
their customers. Many tourists who knew little about cigars before engaging in such a deal were thereby confronted with a "competence-building proposition" (Latour 2005) that supposedly enabled them to make judgements about the quality of the products on offer and assess their price. ${ }^{10}$ Via this reduction of the range of relevant elements indicating quality and price, a convergence of interests between tourists and dealers was supposed to emerge and to turn them into equal and competent, rational, and self-interested economic agents. ${ }^{11}$

My analysis of street-deals has shown how processes of scale-making mimicked those of official production and distribution of cigars when the provenance of the products was traced back to the state and when dealers tried to formalise their status by declaring themselves experts, factory workers and the like. A further oppositional project of scale-making relied on the more limited enactment of a commodity exchange between self-interested individuals. In the next section, I consider a different arena of production and distribution of cigars in Cuba that follows yet another scale-making project. My analysis of deployments of tobacco and cigars in the rural town of Viñales, particularly by local farmers, highlights modes of production and forms of transaction in which competing scales and realities materialise. In this setting, the official production chain analysed in the section on factory tours was unsettled - and along with it the idea of a "communist commodity". In Viñales, we enter a realm of relationships significantly different from market exchanges in Havana because numerous elements not relevant for the exchanges in the official shops and on the streets of the capital were central to the exchanges there. In the valley, cigars embodied some surprises both to the tourist and the researcher as they were no longer "(communist) commodities" but "natural and local products".

\section{SCALING "NATURAL/LOCAL CIGARS” IN VIÑALES}

The valley of Viñales, declared UNESCO World Heritage Site in 1999, is a wellknown tourist destination in Cuba, famous for its peculiar hills (mogotes) and its tobacco fields. Tourism in Viñales centres on excursions through the valley. No matter if tourists go by bus, on a bicycle, by foot or on a horseback, most excursions involve stops at the "must-see" attraction of the valley: tobacco fields and farms.

10 Relying on the metaphor of "plug-ins" which people have to "download" in order to become competent actors, and tracing parallels with recent developments in the field of distributed cognition, Latour employs the notion of "competence-building propositions" to underline the co-constructed and situated nature of cognitive abilities (2005: 211 -212). In the case examined here, in order to gain (for the moment at least) the ability to evaluate the quality of cigars, the clues given to tourists by the dealers worked like "downloads" helping to read the different layers that constituted the objects on sale. 11 This is not to dismiss, however, the protagonists' asymmetric positioning in the bargaining situation. For a more thorough consideration of power relations and the (de)stabilization of asymmetries in the realm of touristic encounters in Cuba, see Simoni (2008b). 
On a prototypical tour, tourists stopped by a farm and the farmer explained the "secrets" of tobacco cultivation and cigar-making. Depending on the season, tobacco plants growing on the field served as objects to learn about size, colour, height and quality. Further points of attraction were the secaderos, dim and huge buildings where tobacco leaves were dried for some weeks after harvest. After explanation of processes of collection, drying, and fermentation attention was drawn to the smell, colours, touch and texture of tobacco leaves. Before the end of these excursions, "locally-produced" coffee and fresh fruit juices were offered. The farmer would then show how to roll a cigar - emphasising every gesture and technicality before inviting tourists to roll their own.

After this climax, when tourists had experienced a "competence-building proposition" of a more personal kind, a prototypical visit would end with the farmer offering bundles of 8-10 cigars (Figure 2), carefully packed in palm leaves, for tourists to take home. As in the informal deals on the streets of Havana described above, the way Viñales' farmers offered cigars highlights gaps and deviations from the state-regulated chain of cigar production. Within this chain farmers were supposed to produce tobacco leaves for cigar factories but not to "sell" cigars to tourists. The latter activity could be legally sanctioned and penalized by the Cuban authorities and this was one of the reasons why farmers were hesitant to present their offers of cigars as market transactions. Instead, they preferred to invoke the relational idioms of hospitality - idioms which fitted much better into the overall image of a tourists' visit to the farm and to argue that the cigar bundles had been manufactured from the share of their produce that the government granted them for private consumption. Nevertheless, the amount of cigars offered to tourists by some Viñales' farmers indicates a more systematically organised and parallel chain along which "natural", "local" cigars were produced and distributed. ${ }^{12}$

It is of no surprise that monetary transactions tended to be downplayed in the course of transactions

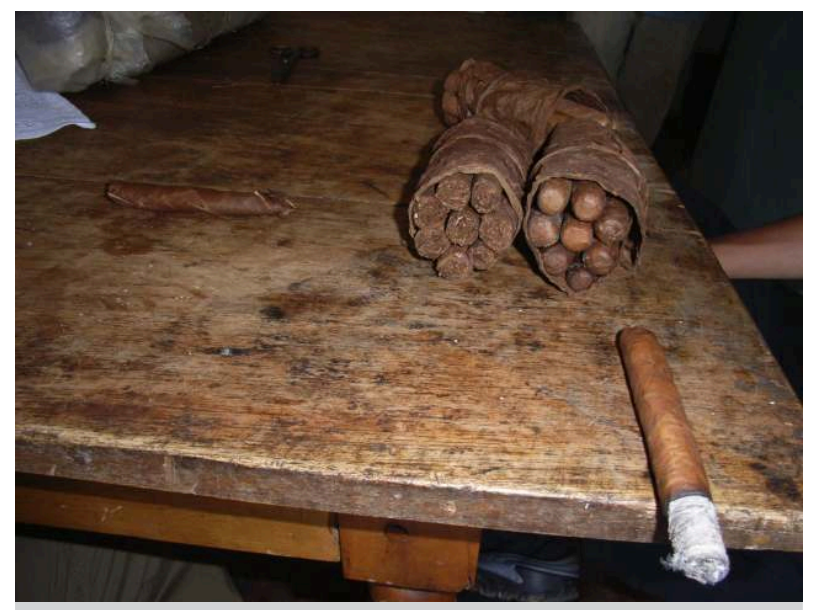

Figure 2 - Bundles of "natural", "locally-produced" cigars. (Photo by Simoni, 2007)

12 Once more, as for street-deals (note 6), my data do not allow me to be more definitive in my considerations on this matter. 
in the valley and on the farms. Indeed, farmers were cautious to avoid clear-cut equivalences and any indications of commoditisation. Exchanges were rather framed as forms of reciprocity, as gifts and counter-gifts (Mauss 1969 [1925]) between hosts and guests. Farmers argued that transactions were about "brindar obsequios" (offering gifts) and were supported by the guides who mediated relations between them and the tourists.

How skilful the farmers were at enticing tourists to reciprocate is evident in the following story. Telling a group of fellow tourists (me among them) what a great time he had had with one of these farmers, a young Austrian man got enthusiastic about sipping a coffee in the sun, sitting by a shack and learning how to roll a cigar, gluing the cigar tip with honey, and then feeling the honey blend in with the taste of the tobacco in the ultimate act of smoking. Before leaving, he and his friends had bought two bundles of ten cigars. As he emphasised, two bundles of "natural cigars" without any "chemical" additives. Central to the exchange were not commodities standardised by labels or brands but unique local products coming directly from the nearby fields, manufactured "on the spot" by those same farmers who had grown and harvested the tobacco. This Viñales' farmer had thus managed to create an atmosphere where elements of the surrounding landscape and rural life blended in with the cigar itself and the experience of smoking, thus creating a unique value grounded in the experience of having been there.

Even when they did not accept the cigar bundles offered to them, most tourists tended to be rather generous in monetary counter-gifts as they had enjoyed being entangled in a regime of reciprocity the farmers had set in motion by making the initial "gifts" of hospitality, fruits, coffee and freshlymade cigars. But still, equivalences between gifts and counter-gifts were hard to figure out as several tourists found it extremely difficult to judge how much money to leave in exchange for the farmer's hospitality. My feeling was that visitors preferred to give in abundance rather than leaving the impression of being stingy. Sometimes normative expectations were made explicit by the accompanying guides who indicated how much to leave and how to be a "good guest" (cf. also Sant Cassia 1999; Tucker 2001).

The example of a typical visit shows how a self-contained reality was progressively produced. This reality relied on a scale-making project which drew together the surrounding fields, the plants, the farmers' skills, the natural and locally-made products into a coherent and unified bundle. Building on Tsing, who considers scale-making projects to be "relatively coherent bundles of ideas and practices as realized in particular times and places" (2000: 347), this highlights how various material entities contributed to the project at stake. It was indeed a convergence of discourses and ideas, of practices and materialities that contributed to outline a direct continuum of metonymic-like relations, 
embodying a scale of locally-grounded, harmonic, and symbiotic relations between "man" and "nature".

However, if one follows MacDonald's remarks on "museums of everyday life", one also needs to consider that - albeit they constitute a "small scale locality" - the deployments of tobacco and cigars by Viñales' farmers can "simultaneously refer to a way of life that is broader than the locality" (2002: 98). As MacDonald mentions for "island life", "rural life" or "the industrial age", the above describes an idealised, potentially transnational/cultural construct of "rural life" where self-sufficient farmers live a harmonious relationship with their immediate surroundings.

Before I return to this strand of analysis in the conclusion, I will now examine how the view of a self-contained reality generated by Viñales' farmers, and the scale-making projects that contributed to frame this reality, were sometimes unsettled, contested, and reformulated. It was the circulation of money that triggered reformulations of and controversies over scale-making projects as soon as notions of self-interested calculation, commoditisation and market exchange conflicted with ideals of reciprocity based on the "local scale" of a "self-contained reality". ${ }^{13}$ In the next section, I show how and when competing versions of chains of cigar production and distribution intersected and thus generated tensions between different scale-making projects.

\section{SHIFTED SCALES AND BLURRED FRAMES: \\ SIMULTANEITY, TENSION AND CONTESTATION}

In contrast to the Havana examples, in Viñales no efforts were made by either farmers or tourists to (re-)entangle tobacco and cigars with factories and state supervision. Instead, a celebration of a "local scale" grounded in a self-contained reality and rustic authenticity was all around. The local farmers appeared to be in charge of the whole chain of production and distribution and this was what made up for "natural cigars". The contrast to the hierarchical organisation and supervision of fragmented and specialised tasks in the factories is obvious. Instead of producing legalised authentic brands, Viñales' farmers, if ever, used negative terms when referring to standardisation and the economic monopoly of the Cuban state. The farmers used the city as a contrast to the realm of

13 The very short time lag between farmers' gifts and tourists' counter-gifts could also rise suspicion of instrumental calculation and breach an ideal view of relationships governed by mutual and disinterested generosity. Callon points to the work of Bourdieu to clarify this issue. The latter has shown how the time lag between gifts and counter-gifts "is the decisive factor between the switch from one regime to another, from calculativeness to non-calculativeness" (Callon 1998: 15). The transitory character of the relationships examined here, and more generally of hospitality in the tourism realm, requires exchanges to unfold in a short time lag. Such transience may lead to increasing difficulties in preserving notions of generosity and non-calculativeness. 
nature, uniqueness, and skilful self-sufficient people in the valley - a realm successfully mediated by tobacco deployments from the field to the farmers' manufacturing tables.

Thus, the narratives of Viñales' farmers contrasted sharply with what happened in Havana and gave shape to very different scales and realities. However, the contrasts that farmers drew between the worlds of tobacco in Havana and Viñales also indicate how these different realities relationally constituted each other. This highlights once more the fundamentally relational nature of scalemaking, as (implicitly or explicitly) different scaling projects in Cuba acquired value in relation to each other. In this sense, the value of "natural/local cigars" offered by Viñales' farmers could only be employed, by farmers and tourists alike, against the backdrop of (and in contrast to) "factory cigars". Furthermore, the frequent evocation of the world of official cigar brands - positively connoted in Havana and negatively connoted in Viñales - reveals imbalances and "power geometries" (Massey 1993) existing between these realities in terms of their reciprocal diffusion and popularity. Brands, state control, official production and distribution were the more powerful players in the game - as exemplified by the transnational promotion and commercialisation of branded Cuban cigars across the world. If such normative views of cigars as commodities controlled and managed by the Cuban government prevailed and came to be seen as "the only good ones", tourists in Viñales would stop attributing much value to the farmers' own confectioning of cigars.

Some tourists, for instance, told me that they had seen cigar making in Havana's factories. They did not want to see it again in Viñales. During excursions in Viñales' countryside they would just have a look at farmers' work in the fields, maybe visit a drying house, while urging their guides to move on when they suggested to stop and to observe how farmers confectioned cigars. Following the canonical script and scale-making project outlined in official narratives about proper procedures of cigar production and distribution, Viñales was only the place where tobacco was grown and dried, whereas rigorous manufacturing took place in factories. The Cuban state supervised these two steps along a single commodity chain, leading to the "real Cuban cigars" that were sold in state-run shops. This is how the scale-making project of the official tourism economy and its associated moralities interfered with the one of Viñales' farmers, leading tourists to ignore and thus to curtail the farmers' options to get a share of the resources in the tourism economy.

Clear-cut boundaries between the worlds of tobacco and cigars in Havana and in Viñales easily became blurred if tourists engaged only partially in the coherent, localised and self-contained rural reality as enacted by Viñales' farmers. In these instances, judgements and evaluations were simultaneously informed by other scale-making projects and scenarios that were concerned with the proper functioning of Cuban society and economy as a (communist) 
whole or the governmentally prescribed chain of production and distribution of cigars. Among tourists' concerns was the price they were asked (or rather discretely suggested) to pay for the bundles of homemade cigars, particularly so if this price contrasted with their views about a suitably proportioned exchange of gifts between hosts and guests. Therefore, even though during farm visits the visibility of monetary transactions was often downplayed when the "hosts" promoted "money as a gift" within a regime of reciprocity, the very same interaction could be rapidly reframed in commercial terms when tourists became preoccupied with "money as payment", commoditisation, and make efforts to attribute objective value to things. Reflecting on why they did not "buy" any cigar bundles from Viñales' farmers, tourists often argued that they did not want to spoil or disrupt the local economy and the functioning of the overall social system by paying an exaggerate amount of money, compared to average Cuban salaries. "If a doctor is really earning 20 convertible pesos a month, how shall we give 10 to a farmer for some handmade cigars? How much would a Cuban pay for that? Are they confectioning and selling cigars because we are tourists?" These were the kinds of questions that came to the fore and enlarged the scale of relevant entities taken into consideration. Thus, money as a means of payment, salaries in Cuba, the impact of tourism on the local economy and even the coherent functioning of Cuban society came to breach the self-contained scale constructed by Viñales' farmers. The two scaling projects, which farmers took such pains to distinguish and differentiate, were redrawn along the prevailing power-geometries and thus generated tensions. My ethnographic material highlights the importance of money, of its conceptions and uses, in shaping scale-making projects and the realities these constitute. However, to view money as straightforwardly shaping realities in this case as an agent of commoditisation - may be too reductive. Instead, following Parry and Bloch (1989), my examples show that what matters are also the transactional orders within which deployments of money gain their significance. Thus, in the interactions that took place on the farms, the money offered by tourists could alternatively be seen as a (counter-)gift - within a regime of reciprocity - or as a payment in a commoditised exchange. In this sense, while on the one hand conceptions and uses of money shape scalemaking processes, on the other hand scale-making processes themselves (and the transactional orders and moralities they bring about) can simultaneously (re)shape conceptions and uses of money. Once again, emphasis on the relational motive - on the relational constitution of money and scales in this case - sharpens our analytical insights. ${ }^{14}$

14 This is also how the anthropology of money can fruitfully reorient itself "from meanings to repertoires, pragmatics, and indexicality" (Maurer 2006: 30) as I have shown elsewhere for the case of tourism in Cuba (Simoni 2008c). 
Clear-cut demarcations between the world of Viñales' tobacco and natural cigars on the one side and that of cigar factories and brands on the other were not only breached by tourists, but also collided with the interests of those non-farmer inhabitants of Viñales who engaged in the sale of branded cigars to tourists in a similar way as the street-dealers of Havana. One of these Viñaleros, for instance, saw the promising deal of a box of Cohiba cigars vanish after tourists who were supposed to buy it ended up with a farmer, enjoyed smoking the "natural cigars" he made for them, and bought ten each. After this experience they renounced the Cohiba deal agreed on earlier. When I told the dealer that they had probably been captivated by the charm of naturally, freshly-made products, he answered with a certain disdain that these were not original cigars: they were "shitty cigars", made in rudimentary ways, without the right twist, the nice finish and external layer. According to him, tourists were overpaying for them. He was not partaking in the self-contained reality promoted by farmers; he was not sharing their scale-making project. More precisely, he was downplaying the disjuncture between a supposedly localised world of farmers and tobacco fields, and the state supervision over the cigar commodity chain, a chain in which the farmers' task was only to furnish tobacco leaves and receive salaries accordingly. His discourse brought the two together, entangling tobacco and cigars in a wider scale - that of official cigar production. But this again was not the scale shared by tourists who cherished this very same disjuncture and the scale-making project which made of Viñales a self-contained world.

\section{CONCLUSION}

The last example highlights the far-reaching consequences of processes of entanglement/disentanglement, of framing what was to be included/excluded from a given deployment of tobacco and cigars, and of widening/restricting the range of entities that made up a certain reality and shaped scaling processes. The success or failure of a deal was highly dependent on how scales were framed, on whether the scale-making projects of tourists and Cubans converged or diverged - at least for the time of the deal. Part of these negotiations was the emergence of relational identifications among actors - identifications as sellers and buyers or as hosts and guests. Thus, these heterogeneous deals were constantly reshaped according to what people understood as market exchange, reciprocity and hospitality. Each deal gave rise to situated translations of these notions and the socialities, agencies and moralities that were attached to them.

In order not to conflate the variety of scale-making projects that proliferate in the contemporary world, Tsing has encouraged scholars to pay attention to those "mixed encounters" and interactions which involve collaboration and 
opposition, dialogue and misunderstanding (Tsing 2000: 348). This article has outlined different scalings of tobacco and cigars in the Cuban tourism economy: from factory tours to dealers offering cigars in the streets of Havana to Viñales' farmers. Along this journey, tobacco and cigars became entangled in different webs of relations, webs that mirror and inform, but also run parallel to each other, thus generating disjunctures and oppositions. A variety of scaling processes were brought about through which "communist Cuba", "self-interested individuals", "hosts and guests", "local rural life" took shape and became realities on which economic transactions were grounded. Tourists collaborated with these framing processes and scaling propositions, but also questioned them and developed other views. When they went along with the scaling projects of street-dealers or Viñales' farmers, a pathway into the tourism economy opened for Cubans and crucial economic resources became available. But if convergence failed and tourists entertained different ideas of scale - following, for instance, the scale-making projects outlined by the official tourism authorities - farmers and street-dealers experienced difficulties to access tourism resources.

Controversies over scale-making projects can have dramatic consequences on people's lives. As Slater has argued, "[f]ramings are political and strategic battle-lines - over liabilities, profits, ethical and political interests" (2002: 243). The same applies to scalings on a different analytical level. Indeed, an emerging and promising research programme investigates "how actors utilize scale categories to spatially 'frame' problems and solutions, include or exclude certain actors, legitimate political projects, rework relations of power and coalesce political processes around particular scalar orders" (Moore 2008: 218 ). Moore encourages us not to neglect the classificatory practices of "lay" actors by which they frequently subvert official categorisations and scalar configurations (2008: 215). This article has shown how the official scale-making project of a communist Cuba articulated in cigar factories and shops could be altered and subverted both in the streets of Havana and on the farms of Viñales. Furthermore, I have highlighted how not only narratives, but also the deployments of materialities such as tobacco, cigars, money, rural landscapes, etc. became active participants in scaling processes and struggles over scale. More than a "discursive fiction", the production of different scales was an encompassing effort that also involved a range of material entities and practices (be it only the diversion of resources from officially prescribed commodity chains). It is through the entanglement of particular ideas, discourses, practices and materialities that different scaling propositions come into being.

Besides scaling processes, different notions of scale have emerged throughout this text, notions which escape confinement within a single model of hierarchically ordered units. Moore (2008: 216) has drawn attention to the variety of spatial images that constitute different notions of scale (e.g. the images 
of container, link, centre-periphery, up-down, part-whole, etc.). Throughout this text, I have translated some of the substance and specificity of the relations and connections established between persons, things, and other entities in Cuba, and thereby grasped the notions of scale that were related to them. In the case of Viñales' farmers, among the specificities of the "modes of connections" (Latour 2007) that linked tobacco and cigars to other entities was their immediacy, a kind of direct continuum, a metonymic relation between fields, plants, farmers' skills, hand/homemade products, discourses of nature, traditional hospitality and reciprocity. Thus, attachments tended to be of an immediate, organic, and simple kind. The notion of scale brought about by Viñales' farmers relied on metonymies, part-whole spatial imagery, and a disjunctive, non-inclusive relationship with the wider Cuban economic system. This is not to deny their simultaneous inclusion within the official state-regulated commodity chain of cigar production. Through their interaction with tourists however, farmers carved another parallel niche to draw resources from. Thus, they resisted the prevailing power geometries not so much by "jumping scales" (Smith 1993) within an ordered hierarchy of "scalar fixes" (Brenner 2001), but by enacting another notion of scale altogether - one of adjacent and opposed spheres (i.e. "natural/local" versus "industrial/global"). In the case of official cigar shops, and to a certain extent even in the case of informal deals on the streets of Havana, the prevalent mode of connection between tobacco, cigars and the realties they contributed to shape, relied less on "natural continuums" than on dislocated, authoritative and legal inscriptions - brands names, logos, stamps, uniforms, badges, receipts, guarantees, professional expertise and coordination, commercial modes of exchange. Attachments were thereby of a more legal, indirect, and complicated kind. The notions of scale at stake in factories and shops relied on images of hierarchic inclusion, of a nationally framed, communist economic system containing, supervising and coordinating the various tasks that lead to the confection and distribution of cigars. In street-deals, scaling processes shifted from tentative inclusions to the wider, state-regulated cigar commodity chain (by evoking factories and trying to "officialise" the status of the dealer), to narrowing the focus to the cigars own qualities and prices, enacting a commodity exchange between individuals.

Deployments of tobacco and cigars gave shape to these different and parallel realities, scaling processes, and notions of scale. Nevertheless, the boundaries of these worlds - which continuously informed each other - were regularly overflowed, blurred and re-negotiated. People could shift from a mode of connection, a frame, a scale, to another quite rapidly. This happened, when informal dealers tried to free their cigars from any external connection and focus attention on their internal qualities only. Alternatively, tourists in Viñales could question the "price" of homemade cigars and widen the frame to include Cuban economy and society, extending scales in size but also changing their 
substance - from a view of separate spheres (of different size), to that of inclusion and containment. Disjunctures and differences were fragile constructs, often only temporarily achieved through the felicitous conjunction of specific ideas, discourses, practices and materialities. Their potentially far-reaching consequences, however, compel us to pay close attention to them.

Besides the processes highlighted above, one can also consider the possibility of scales being reshaped through "extension of semantic reach" and "metonymical and 'intensional' moves" (MacDonald 2002: 98), whereby situated deployments of "rural locality", of "buyer-seller/hosts-guests" relationships, of "communism" (and its subversion) could reach out to acquire transnational/cultural/historic and universalistic connotations. Tourism may be a particularly good vehicle for these kinds of scalar journeys. Indeed, whereas tourism certainly plays on the distinction, uniqueness, and specificity of its attractions, emphasis is also put on providing tourists with experiences of lifestyles and subjectivities that have the potential to transcend the specific. Thereby, the journey from Cuba "the communist - the unique and isolated island" to a Cuba "where universality may be (re-)discovered" becomes possible. The examination of the scaling of tobacco and cigars in the Cuban tourism economy suggests that the realm of tourism is a fertile ground to investigate how competing projects and notions of scale are played out and negotiated in the contemporary world. Tourism appeals to different regimes of value and moral orders, and thrives on diversification. Different scaling projects nourish such diversity, and can thus become crucial arenas of struggle for those people and institutions whose economic trajectories depend on tourism. Cigars in Cuba are sold in bundles, and with these bundles come a variety of scalemaking propositions.

\section{REFERENCES}

BRENNER, Neil, 2001, "The limits to scale? Methodological reflections on scalar structuration”, Progress in Human Geography, 25 (4): 591-614.

BUSCH, Lawrence, 2000, "The moral economy of grades and standards", Journal of Rural Studies, 16: 273-283.

CABEZAS, Amalia L., 2004, "Between love and money: sex, tourism, and citizenship in Cuba and the Dominican Republic", Signs, 29 (4): 984-1015.

CALLON, Michel, 1998, "Introduction: the embeddedness of economic markets in economics", in Michel Callon (ed.), The Laws of the Markets. Oxford and Malden, Basil Blackwell Publishing, 1-57. 
GARCÍA GALLÓ, Gaspar Jorge, 2005 [1961], "La lectura en las tabaquerias”, Catauro: Revista Cubana de Antropologia, 7 (12): 119-124.

KUMMELS, Ingrid, 2005, "Love in the time of diaspora: global markets and local meaning in prostitution, marriage and womanhood in Cuba", Iberoamericana, 5 (20): 7-26.

LATOUR, Bruno, 2005, Reassembling the Social: An Introduction to Actor-Network-Theory. Oxford, Oxford University Press.

—, 2007, "A plea for earthly sciences", keynote lecture for the annual meeting of the British Sociological Association, East London, April 2007. Available at <http://www. bruno-latour.fr/articles/article/102-BSA-GB.pdf> (accessed 06/01/2009).

MACDONALD, Sharon, 2002, "On 'old things': the fetishization of past everyday life", in Nigel Rapport (ed.), British Subjects: An Anthropology of Britain. Oxford, Berg Publishers, 89-106.

MARSTON, Sallie A., 2000, "The social construction of scale", Progress in Human Geography, 24 (2): 219-242.

MASSEY, Doreen, 1993, "Power-geometry and a progressive sense of place", in Jon Bird et al. (eds.), Mapping the Futures: Local Cultures, Global Change. London, Routledge, 59-69.

MAURER, Bill, 2006, “The anthropology of money”, Annual Review of Anthropology, 35: 15-36.

MAUSS, Marcel, 1969 [1925], The Gift: Forms and Functions of Exchange in Archaic Societies. London, Cohen and West.

MOORE, Adam, 2008, "Rethinking scale as a geographical category: from analysis to practice”, Progress in Human Geography, 32 (2): 203-225.

NEVELING, Patrick, 2006, "Spirits of capitalism and the de-alienation of workers: a historical perspective on the Mauritian garment industry", working paper GZAA, MLU HalleWittenberg. Available at <http://www.scm.uni-halle.de> (accessed 07/06/2009).

NEVELING, Patrick, and Carsten WERGIN, 2009, "Projects of scale-making: new perspectives for the anthropology of tourism", this volume.

ORTIZ, Fernando, 2005 [1940], “Del ‘tabaco habano', que es el mejor del mundo, y del 'sello de garantía' de su legitimidad”, Catauro: Revista Cubana de Antropologia, 7 (12): 101-108.

PALMIÉ, Stephan, 2004, "Fascinans or tremendum? Permutations of the state, the body, and the divine in late-twentieth-century Havana”, New West Indian Guide, 78 (3/4): 229-268.

PARRY, Jonathan, and Maurice BLOCH, 1989, Money and the Morality of Exchange. Cambridge, Cambridge University Press.

SANT CASSIA, Paul, 1999, "Tradition, tourism and memory in Malta”, The Journal of the Royal Anthropological Institute, 5 (2): 247-263.

SIMONI, Valerio, 2007. "Tobacco's worlds: tourism, cigars, and the shaping of realities in Cuba", in David Picard and Mike Robinson (eds.), Things that Move: The Material Worlds of Tourism and Travel, Conference Proceedings. Leeds, Centre for Tourism and Cultural Change, Leeds Metropolitan University (CD-Rom).

—, 2008a, “'Riding' diversity: Cubans'/Jineteros' uses of 'nationality-talks' in the realm of their informal encounters with tourists", in Peter Burns and Marina Novelli (eds.), Tourism Development: Growth, Myths and Inequalities. Wallingford, Cambridge, MA, CAB International, 68-84.

— $2008 \mathrm{~b}$, "Shifting powers: the (de)stabilization of asymmetries in the realm of tourism in Cuba", Tsantsa: Review of the Swiss Anthropological Society, 13: 89-97. 
SIMONI, Valerio, 2008c, "Shaping money and socialities in the realm of encounters between foreign tourists and Cubans/Jineteros", paper given at the 2008 EASA Conference, "Experiencing Diversity and Mutuality", Workshop 042, "Relations that money can buy: negotiating mutualities and asymmetries in local and translocal social fields", Ljubljana, August 2008.

SLATER, Don, 2002, "From calculation to alienation: disentangling economic abstractions", Economy and Society, 31 (2): 234-249.

SMITH, Neil, 1993, "Homeless/global: scaling places", in Jon Bird et al. (eds.), Mapping the Futures: Local Cultures, Global Change. London, Routledge, 87-1 19.

STRATHERN, Marilyn, 1996, "Cutting the network", The Journal of the Royal Anthropological Institute, 12 (3): 517-535.

STUBBS, Jean, 2004, "Havana cigars and the West's imagination”, in Sander L. Gilman and Zhou Xun (eds.), Smoke: A Global History of Smoking. London, Reaktion Books, 134-139. SWYNGEDOUW, Erik, 2004, “Globalisation or 'glocalisation'? Networks, territories and rescaling”, Cambridge Review of International Affairs, 17 (1): 25-48.

THOMAS, Nicholas, 1991, Entangled Objects: Exchange, Material Culture, and Colonialism. Cambridge, MA, Harvard University Press.

TSING, Anna, 2000, “The global situation”, Cultural Anthropology, 15 (3): 327-360.

TUCKER, Hazel, 2001, “Tourists and troglodytes: negotiating for sustainability”, Annals of Tourism Research, 28 (4): 868-891.

Configurar a escala dos charutos na economia do turismo em Cuba - Valerio Simoni

- Centre for Tourism and Cultural Change, Reino Unido • vals_sim@yahoo.com

Tomando a escala (Tsing 2000) como objecto de análise, este artigo aborda a forma como emergem projectos concorrentes de configuração de escala a diferentes níveis da economia turística cubana. É examinada a interacção de turistas e cubanos no âmbito de cadeias de produção e distribuição controversas, e as formas como, assim, uns e outros se envolvem em conjuntos de ideias, discursos, práticas e materialidades. Estes constituem diferentes propostas de configuração de escala em que turistas e cubanos convergem ou divergem e que determinam o sucesso dos encontros no seio da economia turística. É aqui sublinhada a importância de compreendermos como as propostas de configuração de escala são apresentadas e negociadas no âmbito do turismo. Conclui-se que o campo do turismo constitui uma plataforma particularmente fértil para o estudo de como noções de escala e projectos de configuração de escala concorrentes se desenvolvem no mundo contemporâneo.

PALAVRAS-CHAVE: charutos, Cuba, economia, escala, tabaco, turismo. 